\title{
小児胚細胞腫の機能予後
}

\author{
金森 政之，斎藤 竜太，冨永 悌二
}

東北大学大学院神経外科学分野

\section{Functional Outcomes of Germ Cell Tumors}

\author{
Masayuki Kanamori, M.D., Ph.D., Ryuta Saito, M.D., Ph.D., and Teiji Tominaga, M.D., Ph.D. \\ Department of Neurosurgery, Tohoku University Graduate School of Medicine
}

Intracranial germ cell tumors are common in adolescents and young adults. Treatment is intended to achieve both tumor control and long-term functional preservation. This review describes the functional outcomes achieved by various treatment strategies for germinoma. Radiation therapy provides high tumor control rates but late complications such as poor performance status, declined intelligence, endocrine disorders, and reduced quality of life may occur. Chemotherapy and reduced dose radiation therapy to the whole ventricle were introduced to avoid these problems without compromising tumor control. Current treatments are reported to preserve intelligence, memory, executive function, and behavior compared to healthy individuals. However, this treatment strategy still has many unsolved problems with longitudinal changes in neurocognitive function and differences in functional outcomes according to the tumor site, age of onset, and other related factors.

Systematic and comprehensive accumulation of information on functional outcomes and construction of an evaluation system based on multi-disciplinary approaches will be necessary to accurately evaluate functional preservation achieved by future therapies.

(Received December 12, 2019; accepted January 9, 2020)

Key words : germinoma, treatment, long-term functional outcomes

Jpn J Neurosurg (Tokyo) $29: 270-278,2020$

\section{はじめに}

頭蓋内胚細胞腫は，日本脳腫瘍統計調査では全脳腫瘍 の $2.1 \%$ 占めるまれな疾患である ${ }^{25)}$. 病理学的には, 胚 腫, 成熟 - 未熟奇形腫, 絨毛癌, 卵黄囊腫瘍, 胎児性癌 からなる疾患群で, 組織型によって摘出, 放射線治療, 化学療法の果たす役割が異なる。本邦では, 1995 年から 松谷らが，組織診断による予後分類を提唱し，それぞれ の予後分類に対する治療開発を進めてきた。この結果, good prognosis group にあたる胚腫では, 10 年生存率
100\%, poor prognosis group でも $56 \%$ と生命予後が改善 している7). その一方で, 長期生存者における機能障害, 内分泌障害などの晚期障害については体系的な解析が限 られている。 その原因として, 症例数が限られているこ と，評価までに長期を要し，その間にも治療方法が変遷 することが挙げられる。

本稿では, 対象疾患を胚細胞腫の中で最も頻度が高 く，腫瘍制御が達成されている胚腫を中心に，時代とと もに変遷した治療方法に対応する長期機能予後について 概説する。また機能予後に影響を及ぼす治療方法以外の 
Table 1 The assessment battery for functional outcomes

\begin{tabular}{l|c|c}
\hline & For children & For adults \\
\hline Intelligence & WISC-III/IV & WAIS-III/IV \\
\hline Kemory & CMS II & WMS-R \\
\hline \multirow{2}{*}{ Attention } & K-ABC II (learning) & CAT \\
& DN-CAS (attention) & FAB \\
& Digit span & TMT-A/B \\
Executive function & DN-CAS (planning) & Digit span \\
& & FAB \\
\hline Social function & CBCL & D-KEFS \\
\hline \multirow{2}{*}{ Quality of life } & PedsQL & ABAS- II \\
& CHQ-PF50 & SF-36 \\
\hline
\end{tabular}

WISC-III/IV : Wechsler Intelligence Scale for Children-third or forth edition, K-ABC II : Kaufman Assessment Battery for Children-second edition, WAIS-III/IV : Wechsler Adult Intelligence Scale-third or fourth edition, CMS : Children Memory Scale, WMS-R : Wechsler Memory Scale-revised edition, DN-CAS : Das-Naglieri Cognitive Assessment System, CAT : Clinical Assessment for Attention, FAB : Frontal Assessment Battery, TMT-A/B : Trail Making Test-A or B, BADS : Behavioral Assessment of the Dysexecutive Syndrome, DKEFS : Delis-Kaplan Executive Function System, CBCL : Child Behavior Check List, ABAS- II : Adaptive Behavior Assessment System-second edition, PedsQL: Pediatric Quality of Life Inventory, CHQ-PF50 : Child Health Questionnaire-Parent Form 50, SF-36 : Short Form-36 Questionnaire, EORTC-QLQ-C30 : The European Organization for Research and Treatment of Cancer QLQ-C30

因子, 他の小児脳腫瘍との違いについても概説を加える.

\section{長期機能予後の評価方法}

過去の報告では，長期機能予後の評価方法は統一され ておらず，治療方法間での比較が困難であることが問題 であった。近年になり臨床試験では，腫瘍制御や有害事 象と併せて長期機能予後について網羅的な情報収集が行 われるようになった。

小児脳腫瘍で長期生存が得られた場合，運動障害・知 覚障害・視力・視野障害などの神経症状は日常生活の妨 げになることは論をまたない。加えて, 高次脳機能障害 は日常診察では見逃されるが，社会生活には大きな影響 を与える症状である。「高次脳機能障害」とは，2001年 度に厚生労働省が策定した「高次脳機能障害支援モデル 事業」の中での疾患区分である ${ }^{8)}$.中核となる症状は (1) 記憶障害, (2)注意障害(単純な作業を集中してできない,

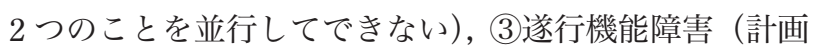

を立てて1つのことを完遂できない)，(4)社会的行動障害 (対人関係が築けない, 情動の制御ができない, ひきこも り）の 4 つである ${ }^{814)}$. 高次脳機能障害に, 知能低下, 精神症状などを加えた症状を「神経心理学的合併症」と 総称し，客観的な指標が開発されている (Table 1)。加 えて患者自身・保護者の主観に基づく quality of life （QoL）評価の重要性も認識され，近年報告が増加してい $ろ^{11) 20(24) 26)}$.

\section{治療方法と長期機能予後の関係について}

\section{1 胚腫に対する治療方法の変遷}

治療方法の変遷については本誌において西川 ${ }^{15)}$ が詳細 な総説を報告している.

1980 年代までは腫瘍局所へ 40〜 $50 \mathrm{~Gy}$ の放射線治療を 基本とした治療が行われ，10 年生存率 $82 \%$ とやや不良 であるという報告もあるが ${ }^{11)}$ ，多くは 10 年生存率 $90 \%$ 以上と良好な腫瘍制御率が報告されている(6)16)24) (Table 


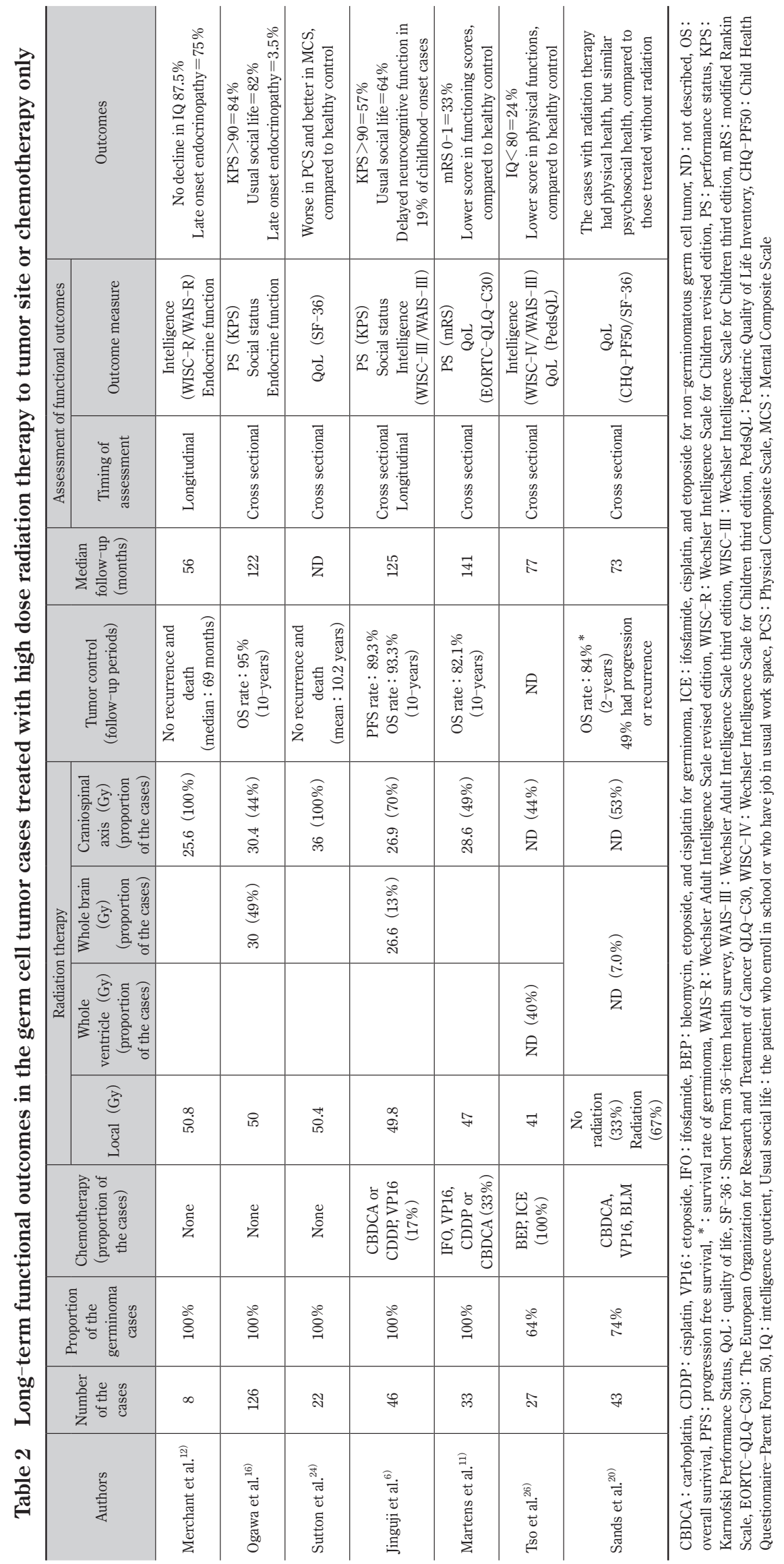


2)。しかし照射による有害事象が認識され，1980 年代後 半からプラチナ製剤を軸とする化学療法の導入 ${ }^{1)}$ と放射 線治療に関しては線量の減量・至適な照射範囲が検討さ れてきた。 機能温存の点から期待された化学療法単独治 療では, 高頻度の再発が認められ, 放射線治療の必要性 が再認識された ${ }^{2}$ 。線量に関しては化学療法併用にて 24 Gy までの減量が可能となった。照射範囲については, 局 所照射では, 全脳照射または全脳室照射と比較して再発 率が高く $(23 \% \mathrm{vs} 8 \%)^{19)}$, 再発の多くは脳室壁に発生す ることから, 全脳室照射によって 5 年, 10 年無再発生存 率・全生存率は $96 \%$ 以上の良好な腫瘍制御が報告されて (る3)7)15). 以上の経緯で現在はプラチナ製剤と全脳室 照射 $24 \mathrm{~Gy}$ が本邦で標準的に行われている治療であ る ${ }^{15)}$ 。北米・欧州でも同様のコンセプトで臨床試験が施 行されている。両者とも化学療法を先行させ, 完全宽解 が得られた症例に全脳室 $18 \mathrm{~Gy}+$ 局所照射 $12 \mathrm{~Gy}$ (北米： ACNS1123 試験), 全脳室 24 Gy (CNS GCT-II 試験) と いう内容である。

\section{2 各治療方法における長期機能予後}

Table 2, 3 に各治療法の腫瘍制御および長期機能予後 についてまとめた。これらの報告では, 患者背景, 評価 時期, 評価内容が多岐にわたり, 系統的なレビューは難 しい.このため, 腫瘍局所に $50 \mathrm{~Gy}$ 前後の照射を基本と した群 (高線量照射群), 化学療法単独群, および化学療 法と 24〜30 Gy の脳室照射を併用する群（化学療法併 用・低線量脳室照射群）に治療方法を分類し，得られた 長期機能予後について概説する.

\section{1. 高線量照射群}

この治療法では, 10 年前後の機能予後について報告さ れている(6)1112)16) (Table 2), 初期治療として, 腫瘍局所 に約 $50 \mathrm{~Gy}$ の放射線治療が施行されていること, 全脳照 射・全脳脊髄照射などの広範囲の照射をうけた症例の割 合が高い特徵がある. Performance status (PS), 社会的 状況, 知能, 内分泌機能, QoL などが評価されている.

Karnofsky Performance Status (KPS) や modified Rankin Scale（mRS）などの PS での評価では, KPS 90 以上を維 持している割合が $84 \%$ とする報告 ${ }^{16)}$ があるものの, KPS 90 以上あるいは mRS 1 以上を維持しているのはそれぞ れ $57 \%^{6)}, 33 \%{ }^{11)}$ と転帰不良を示唆する報告が多い. 就 職などの社会的状況についても治療後 10 年経過すると 18〜36\%で通常の社会生活が営めなくなり ${ }^{6) 16)}$, 治療後 の長い人生を考えると問題は大きい.

これらの PS や社会生活能力の低下の原因となる神経 心理学的基盤や QoLの点から以下のように検討されて
いる.

知能に関して, Jinguji $ら^{6)}$ は, 最終経過観察時に KPS 70 以下の症例は $28 \%$ に存在し, その $75 \%$ で全知能指数 が 80 以下であることを報告している. Merchant ら ${ }^{12)}$ 経時的知能変化についての報告では, 進行性知能低下は 8 例中 1 例のみで, この治療方針で知能は温存されると 報告している.

本治療方針における QoLについて, 包括的尺度である SF-36, PedsQL や疾患特異的尺度である EORTC-QLQ$\mathrm{C} 30$ などで検討されている. SF-36における身体的側 面 ${ }^{24)}$, PedsQLにおける身体的機能 ${ }^{26)}$, EORTC-QLQ-C30 における機能尺度 ${ }^{11)}$ では健常人と比較して有意な低下が 認められ, 一方で SF-36における精神的側面 ${ }^{24)}$, PedsQL における感情・社会的機能 ${ }^{26)}$ は健常人と差がない.これ らの報告から, 患者は精神・社会的側面よりも, 身体的 側面に関して問題を感じているという点が特徴的である.

内分泌機能については, 経過観察中に新規のホルモン 補充療法を要する割合は $3.5 \sim 75 \%$ とばらつきがあ る ${ }^{12) 16) 21)}$. また妊孕性についても内分泌機能の一部とし て報告されている ${ }^{6)}$. Jinguji らの報告では，34 例中男性 4 例（11\%）が治療後に結婚し，2 例の松果体部病変，1 例の神経下垂体部病変の症例で, 挙児が得られたと報告 しており，頻度は低いながら男性では妊孕性が保たれて いる症例がある。

\section{2. 化学療法単独治療}

再発率が高く, 全症例に適応すべき治療方法ではな い. しかし将来, 層別化により, 化学療法単独で治療が できる症例を同定できる可能性があり，照射を回避した 際の機能予後は重要な知見である.

First International Central Nervous System Germ Cell Tumor Study として行われた臨床試験では, 化学療法単 独で初期治療を行う治療戦略について効果を検証してい る. 結果, 胚腫の $42 \%$, 非胚腫性胚細胞腫の $34 \%$ で照射 を行わず腫瘍制御が得られている2).これらの症例につ いて, QoL・知能について検討されている (Table 2). 再 発・残存病変があり放射線治療を要した症例と化学療法 単独治療で腫瘍制御が得られた症例間で Q oLを比較す ると, 照射を回避した症例では, 身体的側面に関する QoLが高いことが示された ${ }^{20)}$. 1 の結果と併せて考える と, 放射線治療が身体的側面の QoLに影響することが示 唆される。

\section{3. 化学療法併用・低線量脳室照射群}

機能予後に関しては, 経過観察期間は短いが, 評価方 法の多様化や機能温存への期待を背景として, 詳細な評 価がなされている（Table 3). 1 の時代は PS, 知能, QoL 


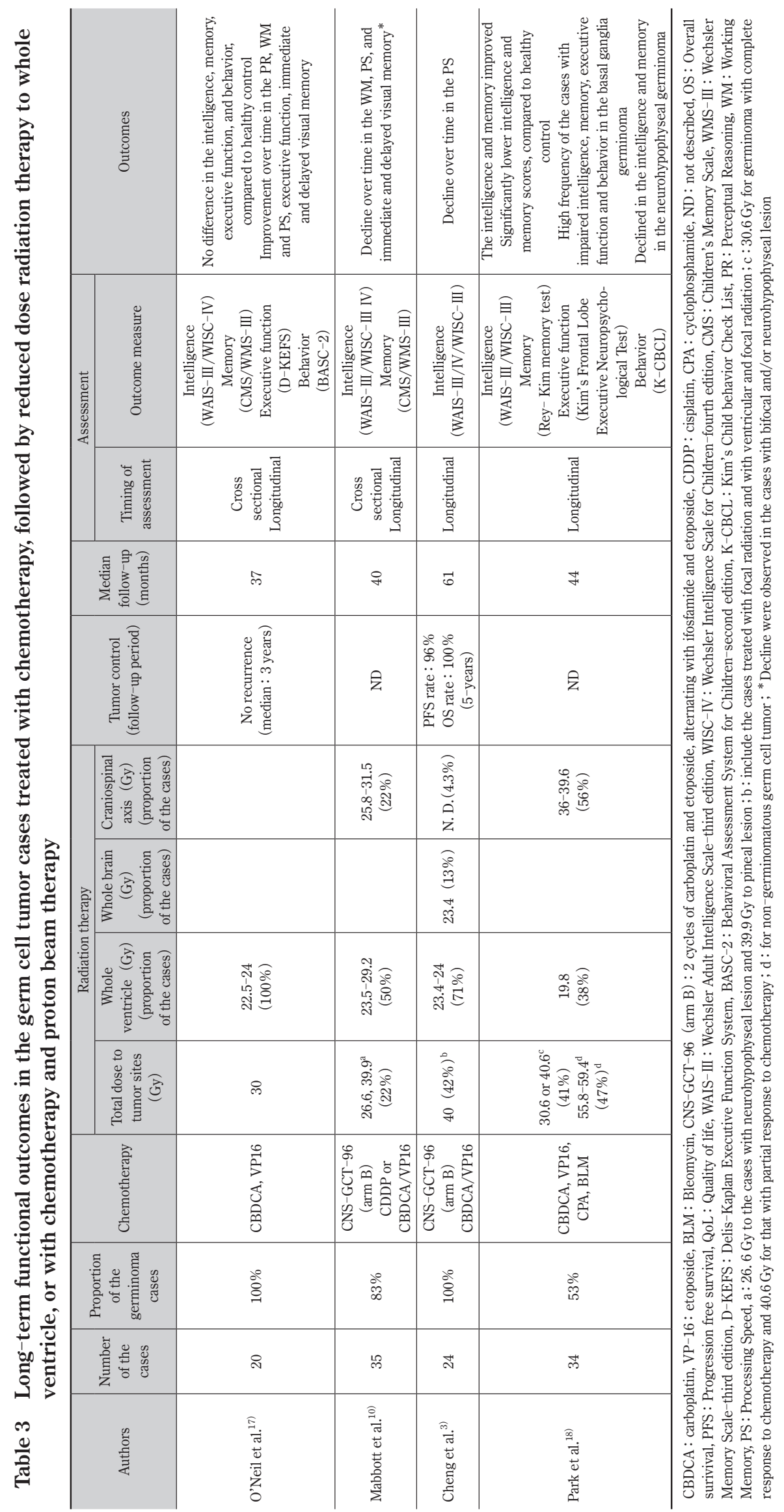

脳外誌 29 巻 4 号 2020 年 4 月 
評価が中心であったが, 遂行機能, 記憶, 社会的行動障 害などの高次脳機能障害を含めた網羅的な検討がされて いる. 以下に本治療方法で長期機能予後がどの程度温存 できているのかについて概説する.

知能に関しては, Wechsler Adult Intelligence Scale (WAIS)-IVまたは Wechsler Intelligence Scale for Children (WISC) -IVによる横断的検討の結果が報告され，健常人 と差がないことが示されている ${ }^{17)}$. 縦断的検討では知覚 統合, 作動記憶, 処理速度が有意に改善したという報 告 ${ }^{17)}$ とこれらが有意に低下するという報告 ${ }^{3) 10)}$ があり結 論は出ていない.

記憶に関する横断的検討でも知能と同様に健常人との 差はないと報告されている ${ }^{17)}$. 経時的には, 即時性, 遅 延性視覚性記憶が改善するという報告 ${ }^{17)}$ と低下する ${ }^{10)}$ と いう相反する報告がある.

遂行機能は，長期生存した患者が社会生活を円滑に行 うために特に重要な機能であり, 通常の社会生活が営め なくなる症例が多い本疾患では, 重要な高次脳機能であ る。遂行機能は，目的をもつた行動を自立して遂行する ための機能で, 行動開始, プランニング, 行為遂行, 自 己調整, 自己抑制, 柔軟性の機能から構成される ${ }^{23)}$.

O’Neil らは20例について Delis-Kaplan Executive Function System にて遂行機能を評価し, 遂行機能全般として は健常人と差はなく,さらに自己抑制の部分が治療によ り改善したと報告している ${ }^{17)}$.

行動異常についても, 社会生活に直結する問題であ り, 実態を明らかにする必要がある。1 17 例の横断的検討 では Behavioral Assessment System for Children Second edition によって行動・感情面の評価がされている ${ }^{17)}$. 約 3 年の時点で, 行動・感情面で異常を呈した症例はない と報告されている。

内分泌機能についても少数例での報告がある ${ }^{3)}$.この 報告では, 神経下垂体病変の症例は 1 例を除きデスモプ レシンの補充の継続が必要であったが, 神経下垂体病変 のない症例では新たな内分泌障害をきたした症例は認め ていない. 経過観察が短いため挙児が得られた症例はな いが，すべての男性患者については凍結精子保存を行い 挙児の可能性を残すべきとしている.

以上のように本治療方法では, 知能, 記憶, 遂行機能, 行動については横断的な検討では健常人と差がなく温存 が達成されている可能性があるが, 経時的変化について は不明である。また内分泌機能についても, 長期の結果 については不明であり, 現状では凍結精子保存, 卵子保 存などの対策を講じるべきと考えられる.

\section{4. 新規治療による機能予後}

胚腫に対する新規治療として陽子線治療の報告があ る。陽子線治療を含む粒子線治療では，ブラッグピーク と呼ばれる線量分布特性があり正常組織への線量低下が 得られ，機能温存が期待できる。この点について小児脳 腫瘍における陽子線治療と X線治療の機能予後の比較で は, 知能, 記憶, 学習到達度, 社会適合すべての点で, 陽子線治療が優れていた ${ }^{5)}$ 。この報告では肧細胞腫は少 数で, 年齢中央值も $7 \sim 8$ 歳と若年であることから, 結果 を胚細胞腫に当てはめることはできない. Park ら ${ }^{18)}$ は, 胚細胞腫を対象として陽子線治療後の縦断的長期機能予 後を報告している（Table 3)。胚腫では全脳室 $19.8 \mathrm{~Gy}$ に 化学療法の反応性に応じた $10.8 \mathrm{~Gy}$ または $19.8 \mathrm{~Gy}$ の追加 局所照射が行われ，知能，記憶に関して経時的にスコア の改善が得られている。その一方で, 知能, 記憶の横断 的評価では，健常人と比較してスコアは依然低值であ り,さらなる検討が必要である。

\section{長期機能予後に影響を与える因子}

\section{1 腫湯の発生部位}

胚腫の好発部位は松果体部, 神経下垂体部, 基底核部 で, それぞれで特徵的な神経学的・内分泌学的徵候を呈 する.これに加え, 神経認知機能についても部位別に相 違があることが報告されている。

$\mathrm{X}$ 線照射や陽子線照射後の知能, 記憶, 精神機能, 遂 行機能, 行動異常, 社会機能などについての腫瘍部位別 の横断的検討では，基底核病変を有する症例において， 他の部位と比較して, すべての項目で機能異常が高頻度 に認められている ${ }^{9) 18)}$ 。基底核は，前頭前野，辺縁系， 間脳・中脳など高次脳機能に関係する部位とネットワー クを形成していることや発症前から多動性・寡動性など

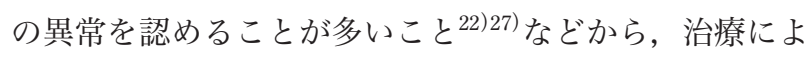
る晚期合併症の要素以外に, このような機能解剖学的な 背景が基盤にあると考えられる 底核胚腫の機能予後は基底核病変に対する局所照射後の 結果であり，本邦で行われている全脳照射後の長期機能 予後については報告がない. 今後腫瘍制御・機能合併症 の点から至適な治療方法を明確にする必要があると考え られる。

部位別の経時的な機能変化についても少数例の報告が ある. Mabbott $~^{{ }^{10)}}$ は, 10 例前後の松果体部, 神経下垂 体部胚腫症例を対象に知能, 言語機能, 記憶, 学業など について縦断的・網羅的解析を行い, 神経下垂体部の症 例では作業速度や視覚性遅延記憶のスコアが経時的に低 
下することを報告している，同様に Park ${ }^{18)}$ は，陽子線 治療後, 神経下垂体部症例では, 言語・動作性知能指数, および知覚統合, 作業速度, 記憶指数の低下をきたし, 他の部位では経時的にスコアが改善することを報告して いる。このような神経下垂体部症例における経時的な機 能低下の原因については, 明らかにされていないもの の, 内分泌学的異常の影響, 側頭葉内側への照射, ウイ リス動脈輪への照射による血管障害などが影響している 可能性がある.

\section{2 治療開始年齢}

多くの小児腫瘍で治療開始年齢が低いことは晚期合併 症出現の危険因子として知られている ${ }^{13)}$. 胚細胞腫に対 する高線量放射線治療においては 12 歳以下に治療を開 始した小児例では，晚期認知機能低下のリスクが高 $\left(^{6) 12)}\right.$. また化学療法単独療法の有効性を検証した臨床 試験 ${ }^{2}$ でも治療時低年齢が知能指数低值に関連すること が報告されている20)。一方で, 化学療法併用・低線量脳 室照射療法では, 14 歳以下の若年者でも, 言語理解, 知 覚統合, 作業記憶, 処理速度において年長児と差はない と報告されている ${ }^{17)}$. 現行の治療方針で, 若年症例の機 能温存が得られている可能性があるが, 症例数が少な く, 今後の検証が必要である.

\section{胚細胞腫以外の小児脳腫瘍の 長期機能予後との相違について}

小児脳腫瘍治療後の知能低下に影響を与える因子とし て, 治療時低年歯, 治療後の長期経過, 女性, 放射線治 療線量・体積, 水頭症の有無などが報告されている ${ }^{13)}$. これらの因子は小児脳腫瘍の病型ごとにプロファイルが 異なり, 長期機能予後は病型別に報告されていることが 多い.

たとえば髄芽腫では発症年齢中央值が 8 歳 25$)$ で後頭蓋 窩に発生し, 広範な放射線治療・多剤化学療法剤にて治 療を行う疾患である。成人まで生存した髄芽腫症例での 横断的機能評価では, 知能, 記憶, 処理速度, 遂行機能, 学業すべてにおいて, 健常人の平均以下のスコアである こと, 縱断的評価では経時的に機能低下が進行すること が報告されている ${ }^{4)}$. 同様に後頭蓋窩上衣腫の中で, 特 に治療に難渋する PFA type では, 発症年㱓が平均 4.9 歳 で摘出, 局所照射が行われるが, 経時的な全知能指数, 作業速度低下が報告されている28)。これに対し, 発症年 齢中央值が 17 歳, 松果体部・神経下垂体部・基底核に好 発部位を有する胚細胞腫の長期機能予後は化学療法併
用・低線量脳室照射によって知能・記憶・遂行機能にお いて健常人と差がないことが報告されている ${ }^{17)}$.

このように肧細胞腫は他の小児脳腫瘍と比較すると, 機能予後は良好である.しかし, 報告ごとに機能予後の 評価時期・評価方法が異なるため単純な比較はできず, 今後の前方視的な情報集積が必須である.

\section{現在までに得られた知見の問題点と 今後の展望}

各治療方法によって得られる長期機能予後温存 ・内分 泌機能温存の成否は, 初診時から治療後の長期経過まで 体系的・縦断的に評価をすることではじめて明らかにな る. 残念ながら, 過去の報告の多くは横断的検討で, 縦 断的検討は少数例の検討に限られる.このため, 従来わ れわれが行ってきた治療法の長期機能予後については明 確な結論が得られていない.このために, 臨床研究・治 験においては, 網羅的・体系的な機能予後評価・内分泌 機能評価を評価項目に含めるようになった。たとえば臨 床試験 ACNS1123 では Standardized Neuropsychological and Behavioral Assessment Battery として知能, 記憶, 処 理速度・注意, 遂行機能, 適応能力, QoL などについて 定期的に評価を行っている．日常診療においても，これ らの評価は実践すべきである. 日本小児がんグループ脳 腫瘍委員会・神経心理評価小委員会から『小览脳腫瘍治 療後の神経心理学的合併症についての手引き』が作成さ $れ^{14)}$, 神経心理学的な評価と, それに続く認知リハビリ テーション，環境調整，教育コースの選択，就労支援な どの介入について具体的な方法が記載されている。この ような多職種の連携を基盤とした網羅的・体系的な評価 体制の構築は，機能予後改善のために推進すべきと考え られる。

著者らは日本脳神経外科学会への自己申告を完了していま す。本論文に関して開示すべき COI はありません。

\section{文 献}

1) Allen JC, Kim JH, Packer RJ : Neoadjuvant chemotherapy for newly diagnosed germ-cell tumors of the central nervous system.J Neurosurg $67: 65-70,1987$.

2) Balmaceda C, Heller G, Rosenblum M, Diez B, Villablanca JG, Kellie S, Maher P, Vlamis V, Walker RW, Leibel S, Finlay $\mathrm{JL}$ : Chemotherapy without irradiation-a novel approach for newly diagnosed CNS germ cell tumors: results of an international cooperative trial. The First International Central Nervous System Germ Cell Tumor Study. J Clin Oncol $14: 2908-2915,1996$. 
3) Cheng S, Kilday JP, Laperriere N, Janzen L, Drake J, Bouffet E, Bartels U: Outcomes of children with central nervous system germinoma treated with multi-agent chemotherapy followed by reduced radiation.J Neurooncol 127:173-180, 2016.

4) Edelstein K, Spiegler BJ, Fung S, Panzarella T, Mabbott DJ, Jewitt N, D’Agostino NM, Mason WP, Bouffet E, Tabori U, Laperriere N, Hodgson DC : Early aging in adult survivors of childhood medulloblastoma: long-term neurocognitive, functional, and physical outcomes. Neuro Oncol 13:536545, 2011.

5) Gross JP, Powell S, Zelko F, Hartsell W, Goldman S, Fangusaro J, Lulla RR, Smiley NP, Chang JH, Gondi V : Improved neuropsychological outcomes following proton therapy relative to $\mathrm{x}$-ray therapy for pediatric brain tumor patients. Neuro Oncol 21: 934-943, 2019.

6) Jinguji S, Yoshimura J, Nishiyama K, Aoki H, Nagasaki K, Natsumeda M, Yoneoka Y, Fukuda M, Fujii Y: Factors affecting functional outcomes in long-term survivors of intracranial germinomas : a $20^{-}$year experience in a single institution. J Neurosurg Pediatr 11:454-463, 2013.

7) Kanamori M, Kumabe T, Saito R, Yamashita Y, Sonoda Y, Ariga H, Takai Y, Tominaga T : Optimal treatment strategy for intracranial germ cell tumors : a single institution analysis. J Neurosurg Pediatr 4:506-514, 2009.

8）国立身体障害者リハビリテーションセンター：「高次脳 機能障害支援モデル事業 中間報告書」の概要。2003. https://www.mhlw.go.jp/houdou/2003/04/h0410-1a.html (2020 年 2 月閲覧)

9) Liang SY, Yang TF, Chen YW, Liang ML, Chen HH, Chang KP, Shan IK, Chen YS, Wong TT : Neuropsychological functions and quality of life in survived patients with intracranial germ cell tumors after treatment. Neuro Oncol $15: 1543-1551$, 2013.

10) Mabbott DJ, Monsalves E, Spiegler BJ, Bartels U, Janzen L, Guger S, Laperriere N, Andrews N, Bouffet E : Longitudinal evaluation of neurocognitive function after treatment for central nervous system germ cell tumors in childhood. Cancer 117: 5402-5411, 2011.

11) Martens $T$, Rotermund $R, Z$ Eulenburg C, Westphal M, Flitsch $\mathrm{J}$ : Long-term follow-up and quality of life in patients with intracranial germinoma. Neurosurg Rev 37 : 445-450, discussion 451, 2014.

12) Merchant TE, Sherwood SH, Mulhern RK, Rose SR, Thompson SJ, Sanford RA, Kun LE : CNS germinoma : disease control and long-term functional outcome for 12 children treated with craniospinal irradiation. Int J Radiat Oncol Biol Phys $46: 1171-1176,2000$.

13) Mulhern RK, Merchant TE, Gajjar A, Reddick WE, Kun LE : Late neurocognitive sequelae in survivors of brain tumours in childhood. Lancet Oncol $\quad \mathbf{5}:$ 399-408, 2004.

14）日本小児がんグループ脳腫瘍委員会 神経心理評価小委 員会編：小児脳腫瘍治療後の神経心理学的合併症につい ての手引き.日本医療研究開発機構研究費・革新的がん 医療実用化研究事業「小児脳腫瘍に対する多施設共同研 究による治療開発」研究報告書.（2020 年公開予定）

15）西川 亮：頭蓋内肧細胞腫の治療. 脳外誌 24:445451, 2015.

16) Ogawa K, Shikama N, Toita T, Nakamura K, Uno T, Onishi H, Itami J, Kakinohana Y, Kinjo T, Yoshii Y, Ito H, Murayama
$\mathrm{S}$ : Long-term results of radiotherapy for intracranial germinoma: a multi-institutional retrospective review of 126 patients. Int J Radiat Oncol Biol Phys 58: 705-713, 2004.

17) O’Neil S, Ji L, Buranahirun C, Azoff J, Dhall G, Khatua S, Patel S, Panigrahy A, Borchert M, Sposto R, Finlay J : Neurocognitive outcomes in pediatric and adolescent patients with central nervous system germinoma treated with a strategy of chemotherapy followed by reduced-dose and volume irradiation. Pediatr Blood Cancer 57:669-673, 2011.

18) Park Y, Yu ES, Ha B, Park HJ, Kim JH, Kim JY : Neurocognitive and Psychological Functioning of Children with an Intracranial Germ Cell Tumor. Cancer Res Treat 49: 960969, 2017.

19) Rogers SJ, Mosleh-Shirazi MA, Saran FH : Radiotherapy of localized intracranial germinoma : time to sever historical ties? Lancet Oncol $\quad$ 6:509-519, 2005.

20) Sands SA, Kellie SJ, Davidow AL, Diez B, Villablanca J, Weiner HL, Pietanza MC, Balmaceda C, Finlay JL : Longterm quality of life and neuropsychologic functioning for patients with CNS germ-cell tumors : from the First International CNS Germ-Cell Tumor Study. Neuro Oncol 3 : 174-183, 2001.

21) Sawamura Y, Ikeda J, Shirato H, Tada M, Abe H : Germ cell tumours of the central nervous system : treatment consideration based on 111 cases and their long-term clinical outcomes. Eur J Cancer 34:104-110, 1998.

22) Sonoda Y, Kumabe T, Sugiyama S, Kanamori M, Yamashita Y, Saito R, Ariga H, Takai Y, Tominaga T : Germ cell tumors in the basal ganglia: problems of early diagnosis and treatment. J Neurosurg Pediatr 2: 118-124, 2008.

23) Stuss DT : Functions of the frontal lobes: relation to executive functions.J Int Neuropsychol Soc 17: 759-765, 2011.

24) Sutton LN, Radcliffe J, Goldwein JW, Phillips P, Janss AJ, Packer RJ, Zhao H : Quality of life of adult survivors of germinomas treated with craniospinal irradiation. Neurosurgery 45: 1292-1297, 1999.

25) The Committee of Brain Tumor Registry of Japan : Report of Brain Tumor Registry of Japan (2005-2008). Neurol Med Chir (Tokyo) 57 Suppl: 14-16, 2017.

26) Tso WWY, Liu APY, Lee TMC, Cheuk KL, Shing MK, Luk CW, Ling SC, Ku DTL, Li K, Yung AWY, Fung CW, Chan SHS, Ho ACC, Ho FKW, Ip P, Chan GCF : Neurocognitive function, performance status, and quality of life in pediatric intracranial germ cell tumor survivors.J Neurooncol 141 : 393-401, 2019.

27) Yeo KK, Kayser K, Margol AS, Wong KK, Robison N, Finlay J, Dhall G : Clinical and neuropsychological outcome of pediatric non-midline central nervous system germinoma treated with chemotherapy and reduced dose/volume irradiation: The Children's Hospital Los Angeles experience. Pediatr Blood Cancer $\quad 66$ : e27983, 2019.

28) Zapotocky M, Beera K, Adamski J, Laperierre N, Guger S, Janzen L, Lassaletta A, Figueiredo Nobre L, Bartels U, Tabori U, Hawkins C, Urbach S, Tsang DS, Dirks PB, Taylor MD, Bouffet E, Mabbott DJ, Ramaswamy V : Survival and functional outcomes of molecularly defined childhood posterior fossa ependymoma : Cure at a cost. Cancer 125: 1867-1876, 2019. 
小児胚細胞腫の機能予後

\section{金森 政之 斎藤 竜太 冨永 悌二}

胚細胞腫は思春期・若年成人に好発し, 腫瑒制御のみならず, 機能温存を目標とすべき疾患である. 胚細胞腫の中で頻度が多い胚腫では，機能温存を目指した治療開発が行われてきた．初期の放射線治 療単独治療では, 高い腫瘍制御率が得られるが, 長期経過後の performance status, 社会適応能力の 低下, 特に治療時低年齢症例での知能低下, 内分泌障害, quality of life (QoL) 低下などの晚期合併 症を生じる. 近年導入された化学療法併用低線量全脳室照射では, 知能, 記憶, 遂行機能, 社会機能 などの温存が得られている可能性がある. しかし経過観察期間・症例数とも不十分で継続的な評価が 必要である. 長期機能予後の評価には膨大な時間と労力を要するが, 体系的・網羅的な情報蓄積・多 職種での評価体系の構築が必要である. 